\title{
Heavy Metals and Major Ionic Pollution Assessment in Waters of Midstream of the River Karatoa in Bangladesh
}

\author{
H. M. Zakir ${ }^{1}$, M. Moshfiqur Rahman' ${ }^{1}$, A. Rahman ${ }^{1}$, I. Ahmed ${ }^{1}$ and M. A. Hossain ${ }^{2}$ \\ ${ }^{1}$ Department of Agricultural Chemistry, Faculty of Agriculture, Bangladesh Agricultural University, \\ Mymensingh-2202, Bangladesh. \\ ${ }^{2}$ Naogaon Government College, Naogaon, Bangladesh
}

\begin{abstract}
In a quantitative assessment of water collected from the midstream of Karatoa river in Bangladesh, 31 water samples were analyzed to assess heavy metals, major ionic constituents and suitability parameters for irrigation usage. The electrical conductivity of all collected samples were within the range of 450 to $1653 \mu \mathrm{S} \mathrm{cm}^{-1}$ indicating medium to high salinity. Total dissolved solids ranged from 247 to $789 \mathrm{mg} \mathrm{L}^{-1}$ and the samples were rated as fresh water $\left(<1000 \mathrm{mg} \mathrm{L}^{-1}\right)$. The anion chemistry in the Karatoa river water was dominated by $\mathrm{HCO}_{3}{ }^{-}$and $\mathrm{Cl}^{-}$, which contributed 66 and $31 \%$, respectively of the total anionic mass balance. On the other hand, the cation chemistry indicated that 8 samples showed dominance sequence as $\mathrm{Ca}>\mathrm{Mg}>\mathrm{Na}>\mathrm{K}, 8$ samples as $\mathrm{Ca}>\mathrm{K}>\mathrm{Na}>\mathrm{Mg}, 7$ samples as $\mathrm{Ca}>\mathrm{Mg}>\mathrm{K}>\mathrm{Na}, 6$ samples as $\mathrm{Ca}>\mathrm{Na}>\mathrm{K}>\mathrm{Mg}$ and only 2 samples as $\mathrm{Ca}>\mathrm{K}>\mathrm{Mg}>\mathrm{Na}$. Among the studied heavy metals ( $\mathrm{Fe}, \mathrm{Mn}, \mathrm{Cu}, \mathrm{Zn}, \mathrm{Pb}, \mathrm{Cr}$ and $\mathrm{Ni}$ ), the most dominant metal was $\mathrm{Fe}$ and $\mathrm{Mn}$. The concentration of $\mathrm{Mn}$ in 13 water samples exceeded the surface water quality standard $\left(0.10 \mathrm{mg} \mathrm{L}^{-}\right.$ ${ }^{1}$ ) indicating Mn toxicity. Considering hardness, 6 water samples were graded as moderately hard while the rest 25 samples were graded as hard. As regards to permeability index, $65 \%$ of the water samples collected from the midstream of Karatoa river belongs to the unsuitable category.
\end{abstract}

Keywords- Water pollution, surface \& irrigation water quality, Karatoa river

\section{Introduction}

The contamination of water with heavy metals is a major environmental problem. Some of these metals are potentially toxic or carcinogenic at high concentrations and can cause serious health hazard if they enter into the food chain. Heavy metals like $\mathrm{Cu}$, $\mathrm{Zn}, \mathrm{Mn}, \mathrm{Fe}, \mathrm{Ni}, \mathrm{Cd}, \mathrm{Cr}, \mathrm{Co}, \mathrm{Pb}$ etc. are usually present in water at low concentration, but enhanced concentration of these metals have found as a result of human activities. Investigation have been made in different countries by different researchers on the extent of heavy metals pollution in surface water, ground water, soil, sediments and vegetation (Zakir et al., 2006; Mohiuddin et al., 2010; Akbal et al., 2011; Zakir et al., 2011; Shikazono et al., 2012).

It is reported that a large number of rivers and streams drain to the undulating landscape of the Jaintia Hills. Most of these rivers and streams flow towards south-east into the flood plains of Bangladesh and a few towards northern side into the Brahmaputra valley (Das et al., 2002). The water is seriously affected by contamination of heavy metals originating from different industries and spoils, leaching of heavy metals, organic enrichment and silting by sand particles. Pollution of the water is evident by the colour of the water which in most of the rivers and streams in the industrial area varies from brownish to reddish orange. The experimental water samples were collected from the major polluting areas of midstream of the river Karotoa under sadar district of Bogra, Bangladesh. There are several types of industrial units including textile, dying, pharmaceuticals, leather and others present in Bogra. From the different industrial zones of the area, contamination of river water by various metallic and non-metallic chemicals are very common. Ittefaq (2010) reported that the toxic waste, sewerages and effluents of more than hundred factories are being discharged to Karatoa river. Nowadays, offensive odour from this river are making nuisance to the people living surrounding areas. Huge amount of untreated municipal waste water, industrial effluents and others may associate with the heavy metal contamination in water of Karatoa river, which has been used by nearby villagers for irrigation, animal watering, bathing and washing etc. for the last several decades, and may have a significant contribution to increase heavy metal content of the surrounding water. As a result, environmental hazards are occurring including different health hazards.

This loading of toxic metals often leads to degradation of water health and contamination of food chain mainly through the crops produced using contaminated irrigation water. However, there is no systemic research report yet about the heavy metal pollution level and major ionic constituents in midstream waters of the Karatoa river in Bangladesh. Considering the above facts, the research work has carried out to determine the concentration of heavy metals and major ionic constituents of the Karatoa river in Bangladesh as well as to assess the suitability of waters for irrigation. 


\section{Materials and Methods}

A total of 31 water samples were collected from the midstream of Karatoa river during March in 2011 following the sampling techniques as outlined by APHA (1995) and Sincero and Sincero (2004) (Table 1). Samples were collected in $500 \mathrm{ml}$ narrow- mouth high density polyethylene bottles, which were cleaned in the laboratory with dilute $\mathrm{HCl}(1: 1)$ and then rinsed twice with distilled water. Before sampling, bottles were also rinsed with the sampled water. For heavy metal analysis, $100 \mathrm{ml}$ samples were acidified with $\mathrm{HNO}_{3}$ and preserved separately in refrigerator.In the laboratory of the Department of Agricultural Chemistry, Bangladesh Agricultural University, Mymensing-2202, the water samples were filtered through $0.45 \mu \mathrm{m}$ Millipore membrane filters to separate undesirable solid and suspended materials. The samples were analyzed for $\mathrm{pH}$, electrical conductivity (EC), total dissolved solids (TDS), dissolved oxygen (DO), major cations $\left(\mathrm{Ca}^{2+}\right.$, $\mathrm{Mg}^{2+}, \mathrm{Na}^{+}$and $\left.\mathrm{K}^{+}\right)$, major anions $\left(\mathrm{Cl}^{-}, \mathrm{HCO}_{3}{ }^{-}, \mathrm{CO}_{3}{ }^{2-}\right.$, $\mathrm{SO}_{4}{ }^{2-}, \mathrm{BO}_{3}{ }^{3-}$ and $\mathrm{PO}_{4}{ }^{3-}$ ) and heavy metals (Fe, $\mathrm{Mn}$, $\mathrm{Zn}, \mathrm{Pb}, \mathrm{Cr}, \mathrm{Ni}$ and $\mathrm{Cu}$ ) following standard analytical methods. Calcium and magnesium were determined titrimetrically using standard EDTA. Chloride was measured by standard $\mathrm{AgNO}_{3}$ titration, bicarbonate and carbonate by titration with standard $\mathrm{H}_{2} \mathrm{SO}_{4}$, sodium and potassium by flame photometry. Sulphate, borate and phosphate were determined by spectrophotometry. The concentrations of Fe, Mn, $\mathrm{Zn}, \mathrm{Pb}, \mathrm{Cr}, \mathrm{Ni}$ and $\mathrm{Cu}$ in water samples were analyzed by atomic absorption spectrophotometer by using single hallow cathode lamp at the wavelengths of $248.3,279.5,213.9,283.3,357.9,232.0$ and 324.7 $\mathrm{nm}$, respectively following the procedure as described by APHA (1995). The analytical precision for ions was determined by the ionic balances calculated as $100 \times$ (cations - anions)/ (cations + anions), which is generally within $\pm 5 \%$ (Srinivasamoorthy et al., 2011). The parameters such as sodium adsorption ratio (SAR), soluble sodium percent (SSP), residual sodium carbonate (RSC), permeability index $(\mathrm{PI})$ and hardness $\left(\mathrm{H}_{\mathrm{T}}\right)$ were calculated to evaluate the suitability of the water quality for agricultural purposes. Further the results of the analyses were interpreted using graphical representations like SAR vs salinity hazard as described by Richards (1968) and Doneen plot (Doneen 1964).

\section{Results and Discussion}

The results of the geochemical analysis of water samples collected from midstream of the river Karatoa is given in Tables $2 \& 3$. Figure 1 shows the percent contribution of individual ions towards the total cationic and anionic mass balance.

\section{a) Physicochemical properties of water}

The $\mathrm{pH}$ of water samples collected from midstream of Karatoa river fluctuated between 6.98 to 7.70 with a mean value of 7.28 indicating neutral to little alkalinity of water (Table 2). These might be due to the presence of ions such as $\mathrm{Ca}, \mathrm{Mg}$ and $\mathrm{Na}$ in water (Rao et al., 1982). According to Ayers and Westcot (1985), the acceptable range of $\mathrm{pH}$ for irrigation water is from 6.5 to 8.4. So, on the basis of measured $\mathrm{pH}$ of all samples collected from the Karatoa river was not problematic for long-term irrigation. Conductivity is the measure of the capacity of a solution to conduct electric current. The electrical conductivity (EC) of all collected water samples were within the range of 450 to $1653 \mu \mathrm{S} \mathrm{cm} \mathrm{cm}^{-1}$ with an average of $763.81 \mu \mathrm{S} \mathrm{cm}^{-1}$ (Table 2). Among the 31 samples, EC of 25 were less than their average value and the rest 06 samples were higher than the average. There were a wide spatial variations observed in the EC of waters of Karatoa river. A similar observation was reported by Singh et al. (2010) for waste water of Raniganj industrial area in India. According to Richards (1968), samples under test were rated in the category $\mathrm{C} 2\left(\mathrm{EC}=250-750 \mu \mathrm{Scm}^{-1}\right)$ and $\mathrm{C} 3(\mathrm{EC}=$ $751-2250 \mu \mathrm{S} \mathrm{cm} \mathrm{cm}^{-1}$ ) indicating medium to high salinity. Medium salinity class water might be applied with moderate leaching but high salinity class waters were treated as unsuitable for irrigation (Agarwal et al., 1982). Dissolved oxygen (DO) of all collected water samples were within the range of 0.3 to $0.5 \mathrm{mg} \mathrm{L}^{-1}$ with an average of $0.42 \mathrm{mg} \mathrm{L}^{-1}$ (Table 2 ). Adequate dissolved oxygen is necessary for good water quality. As dissolved oxygen levels in water drop below $5.0 \mathrm{mg} \mathrm{L}^{-1}$, aquatic life is put under stress. The lower the concentration, the greater the stress (DEP, 2010). Total dissolved solids (TDS) values of water samples collected from midstream of the river Karatoa were within the range of 247 to 789 $\mathrm{mg} \mathrm{L}^{-1}$ with an average value of $324.87 \mathrm{mg} \mathrm{L}^{-1}$ (Table 2). All water samples containing TDS $<1000 \mathrm{mg} \mathrm{L}^{-1}$ were rated as fresh water (Freeze and Cherry, 1979). High TDS values indicated the presence of an appreciable quantities of bicarbonates, sulphates and chlorides of $\mathrm{Ca}, \mathrm{Mg}$ and $\mathrm{Na}$ (Karanth, 1994).

\section{b) Major anionic constituents in water}

Water samples collected from the study area contained $\mathrm{Cl}^{-}$ranging from 2.61 to 5.36 me $\mathrm{L}^{-1}$ with an average value of $3.12 \mathrm{me} \mathrm{L}^{-1}$ (Table 2), which contributed $31 \%$ of the total anionic mass balance (Fig. 1a). Maximum permissible limit of $\mathrm{Cl}^{-}$in irrigation water is $4.00 \mathrm{me} \mathrm{L}^{-1}\left(141.80 \mathrm{mg} \mathrm{L}^{-1}\right)$ as reported by Ayers and Westcot (1985). On the basis of this limit, all water samples except 3 (Sample ID 16, 19 and 31) were within the permissible limit, and these water were suitable for irrigation. Excess chloride in the study area may result from anthropogenic sources including agricultural runoff, domestic and industrial wastes and leaching of saline 
residues in the water (Appelo and Postma, 1993). According to DEP (2010), maximum recommended concentration of $\mathrm{Cl}^{-}$in surface water is $250 \mathrm{mg} \mathrm{L}^{-1}$. Considering this limit as standard, amount of $\mathrm{Cl}^{-}$in all water samples of the study area were below the recommended value, which also indicates that all the water samples were suitable for different uses. The concentration of $\mathrm{HCO}_{3}{ }^{-}$in water samples was within the range of 2.0 to $8.0 \mathrm{me} \mathrm{L}^{-1}$ with the mean value of $2.59 \mathrm{me} \mathrm{L}^{-1}$ (Table 2) and it contributed $66 \%$ of the total anionic mass balance (Fig. 1a). Among the 31 samples, $67.74 \%$ samples were less than the mean value and the other $32.26 \%$ samples were higher than the mean value. In respect of $\mathrm{HCO}_{3}{ }^{-}$content, all of the studied water samples were found unsuitable for irrigation, which exceeded the recommended limit (1.50 me $\mathrm{L}^{-1}$ ) as reported by Ayers and Westcot (1985). Bicarbonates are derived mainly from the soil zone $\mathrm{CO}_{2}$ and dissolution of carbonates and reaction of silicates with carbonic acid. The soil zone in the subsurface environment contains elevated $\mathrm{CO}_{2}$ pressure (produced as result of decay of organic matter and root respiration), which in turn combines with rainwater to form bicarbonate. Bicarbonate may also be derived from the dissolution of carbonates and/or silicate minerals by the carbonic acid (Singh et al., 2009). The phosphate content of test samples collected from midstream of the Karatoa river varied from 1.13 to $2.56 \mathrm{mg} \mathrm{L}^{-1}$ with a mean value of 1.58 $\mathrm{mg} \mathrm{L}{ }^{-1}$. The maximum permissible limit of $\mathrm{PO}_{4}{ }^{3-}$ in irrigation water is $2.00 \mathrm{mg} \mathrm{L}^{-1}$ (Ayers and Westcot, 1985). Considering this limit as standard, out of the 31 samples, 26 samples were within the permissible value. The $\mathrm{SO}_{4}{ }^{2-}$ content of all water samples collected from the study area ranged from 3.08 to $25.92 \mathrm{mg} \mathrm{L}^{-1}$ with a mean value of $7.43 \mathrm{mg} \mathrm{L}^{-1}$ (Table 2) and it contributed only $2 \%$ of the total anionic mass balance (Fig. 1a). The maximum permissible limit of $\mathrm{SO}_{4}{ }^{2-}$ in irrigation water is 20.0 $\mathrm{mg} \mathrm{L}^{-1}$ (Ayers and Westcot, 1985). Out of the 31 samples, 29 samples were within the permissible value and suitable for irrigation. The $\mathrm{BO}_{3}{ }^{3-}$ content of all water samples ranged from 0.30 to $1.35 \mathrm{mg} \mathrm{L}^{-1}$ with a mean value of $0.59 \mathrm{mg} \mathrm{L}^{-1}$ (Table 2). The maximum permissible limit of $\mathrm{BO}_{3}{ }^{3-}$ in irrigation water is $1.00 \mathrm{mg} \mathrm{L}^{-1}$ (Ayers and Westcot, 1985). Out of the 31 samples, 30 samples were within the permissible value and suitable for irrigation. Because boron is weakly absorbed in soil, marginal levels in irrigation water reportedly may not be immediately toxic; however, continued use exceeding specified levels cannot be tolerated by the plants (Gibeault and Cockerham, 1985). According to DEP (2010), the maximum permissible limit of $\mathrm{BO}_{3}{ }^{3-}$ in surface water is $0.75 \mathrm{mg} \mathrm{L}^{-1}$. Out of the 31 samples, 27 samples were within the permissible value and suitable for different uses.

Table 1. Detailed information regarding water sampling sites at midstream of Karatoa river in Bangladesh

\begin{tabular}{ccc}
\hline Sample ID. & Sampling area & Possible source of contamination \\
\hline 01 & SP ghat & Sewage sludge \\
02 & SP ghat & Sewage sludge \\
03 & SP ghat & Sewage sludge \\
04 & SP ghat & Sewage sludge \\
05 & SP ghat & Sewage sludge \\
06 & SP ghat & Sewage sludge \\
07 & Bogra Mohila Mohabiddaloy & Pharmaceutical waste \\
08 & Bogra Mohila Mohabiddaloy & Pharmaceutical waste \\
09 & Bogra Mohila Mohabiddaloy & Pharmaceutical waste \\
10 & Bogra Mohila Mohabiddaloy & Pharmaceutical waste \\
11 & Bogra Mohila Mohabiddaloy & Pharmaceutical waste \\
12 & Bogra Mohila Mohabiddaloy & Pharmaceutical waste \\
13 & Backside of DC Office & Hide processing waste \\
14 & Backside of DC Office & Hide processing waste \\
15 & Backside of DC Office & Hide processing waste \\
16 & Backside of DC Office & Hide processing waste \\
17 & Backside of DC Office & Hide processing waste \\
18 & Backside of DC Office & Hide processing waste \\
19 & Fatah Ali Bridge & Industrial effluent \\
20 & Fatah Ali Bridge & Industrial effluent \\
21 & Fatah Ali Bridge & Industrial effluent \\
22 & Fatah Ali Bridge & Industrial effluent
\end{tabular}




\begin{tabular}{ccc}
\hline Sample ID. & Sampling area & Possible source of contamination \\
\hline 23 & Fatah Ali Bridge & Industrial effluent \\
24 & Fatah Ali Bridge & Industrial effluent \\
25 & Chasi Bazar & Municipal waste \\
26 & Chasi Bazar & Municipal waste \\
27 & Chasi Bazar & Municipal waste \\
28 & Chasi Bazar & Municipal waste \\
29 & Chasi Bazar & Municipal waste \\
30 & Chasi Bazar & Municipal waste \\
31 & Chasi Bazar & Municipal waste \\
\hline
\end{tabular}

\section{$\left\|\mathrm{Cl}^{-}\right\| \mathrm{HCO}_{3}^{-} \quad \mathrm{SO}_{4}^{2-} \quad \mathrm{PO}_{4}^{3-}$}

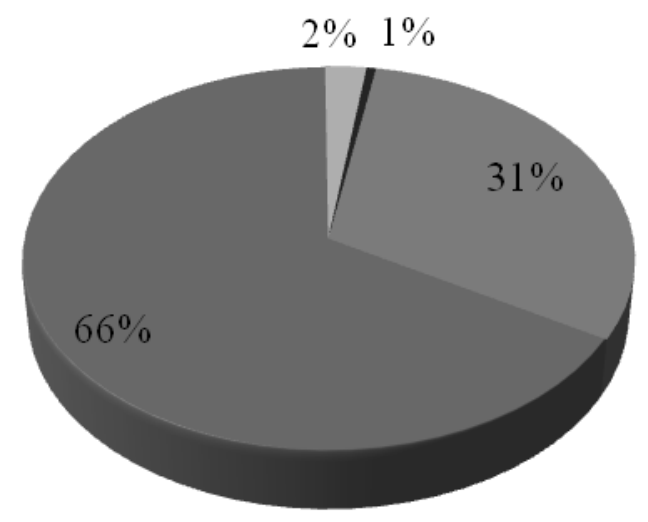

$\mathbf{a}$

\section{$\left\|\mathrm{Ca}^{2+} \square \mathrm{Mg}^{2+}\right\| \mathrm{Na}^{+} \| \mathrm{K}^{+}$}

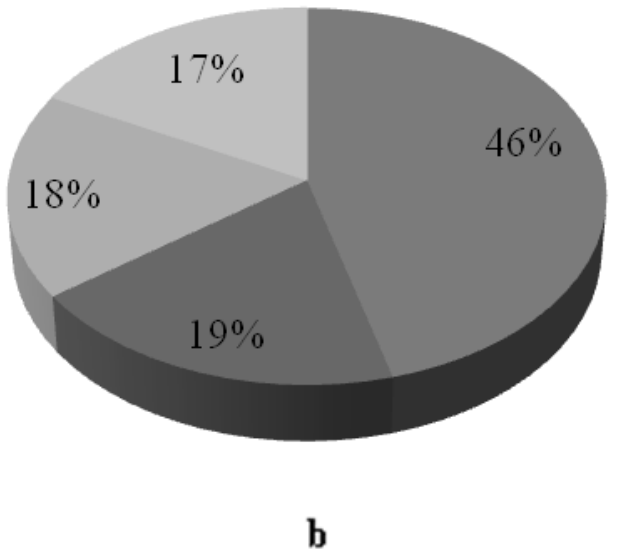

Fig. 1. Contribution of individual major ions towards the total anionic (a) and cationic (b) mass balance in water of midstream of Karatoa river in Bangladesh

\section{c) Major cationic constituents in water}

The major cations measured from collected water samples of midstream of the river Karatoa were expressed as $\mathrm{mg} \mathrm{L}^{-1}$ (Table 3 ). The cation chemistry was dominated by calcium, sodium, potassium and magnesium in the water of the major polluting areas of Karatoa river. Among the 31 water samples, 8 samples showed dominance sequence as $\mathrm{Ca}>\mathrm{Mg}>$ $\mathrm{Na}>\mathrm{K}, 8$ samples as $\mathrm{Ca}>\mathrm{K}>\mathrm{Na}>\mathrm{Mg}$, 7 samples as $\mathrm{Ca}>\mathrm{Mg}>\mathrm{K}>\mathrm{Na}, 6$ samples as $\mathrm{Ca}>\mathrm{Na}>\mathrm{K}>$ $\mathrm{Mg}$ and only 2 samples as $\mathrm{Ca}>\mathrm{K}>\mathrm{Mg}>\mathrm{Na}$. Weathering of rock forming minerals and cation exchange processes normally control the levels of these cations. High concentrations of $\mathrm{Ca}$ and $\mathrm{Mg}$ in the water are attributed to the weathering of crystalline dolomitic limestones and $\mathrm{Ca}-\mathrm{Mg}$ silicates (amphiboles, pyroxenes, olivine, biotite and others) (Ghosh et al., 1983). The sodium and potassium in the aquatic system were derived from the atmospheric deposition, evaporate dissolution and silicate weathering. The weathering of $\mathrm{Na}$ and $\mathrm{K}$ silicate minerals like albite, anorthite, orthoclase and microcline may be the possible source of $\mathrm{Na}$ and $\mathrm{K}$ in water of the study area (Singh et al., 2009).

The content of $\mathrm{Ca}$ in water samples collected from the midstream of the river Karatoa varied from 24.05 to $70.54 \mathrm{mg} \mathrm{L}^{-1}$ with an average value of $44.32 \mathrm{mg} \mathrm{L}^{-1}$ (Table 3 ) and it contributed $46 \%$ of the total cationic mass balance (Fig. 1b). The contribution of $\mathrm{Ca}$ in water was largely dependent on the solubility of $\mathrm{CaCO}_{3}, \mathrm{CaSO}_{4}$ and rarely on $\mathrm{CaCl}_{2}$ (Karanth, 1994). Irrigation water containing less than $20 \mathrm{me} \mathrm{L}^{-1}(800$ $\mathrm{mg} \mathrm{L}^{-1}$ ) Ca is suitable for irrigating crops (Ayers and Westcot, 1985). On the basis of Ca content, all water samples could safely be used for irrigation. The concentration of $\mathrm{Mg}$ was detected within the range of 3.89 to $30.13 \mathrm{mg} \mathrm{L}^{-1}$ with a mean value of $15.84 \mathrm{mg}$ $\mathrm{L}^{-1}$ (Table 3), which contributed $19 \%$ of the total cationic mass balance (Fig. 1b). According to Ayers and Westcot (1985), irrigation water containing below $5.0 \mathrm{me} \mathrm{L}^{-1}\left(121.5 \mathrm{mg} \mathrm{L}^{-1}\right) \mathrm{Mg}$ is suitable for crops and soils. In the investigated areas, all water samples were within this recommended limit, and could safely be used for irrigation and would not affect soils of the 
study area. The concentration of $\mathrm{Na}$ in water of the study area varied from 12.48 to $24.88 \mathrm{mg} \mathrm{L}^{-1}$ with the mean value of $15.94 \mathrm{mg} \mathrm{L}^{-1}$ (Table 3), which contributed $18 \%$ of the total cationic mass balance (Fig. 1b). Sodium in the aquatic system is mainly derived from atmospheric deposition; evaporate dissolution and silicate weathering (Berner and Berner, 1987). According to Ayers and Westcot (1985), irrigation water generally containing less than $40 \mathrm{me} \mathrm{L}^{-1} \mathrm{Na}$ is suitable for crops and soils. The detected $\mathrm{Na}$ content in all the water samples under test were far below this specified limit. Water for irrigation should satisfy the needs of soil and plants of the area for normal growth and crop production. The concentration of $\mathrm{K}$ present in the water samples collected from midstream of the river Karatoa varied from 8.55 to $21.53 \mathrm{mg} \mathrm{L}^{-1}$ with the mean value of $15.03 \mathrm{mg} \mathrm{L}^{-1}$ (Table 3) and it contributed $17 \%$ of the total cationic mass balance (Fig. 1b). According to Ayers and Westcot (1985), the recommended limit of $\mathrm{K}$ in irrigation water is $2.0 \mathrm{mg} \mathrm{L}^{-1}$. In the investigated area, all of the water samples exceeded the limit.

\section{d) Heavy metals concentration in water}

In the water samples collected from midstream of the river Karatoa, the most dominant metal was $\mathrm{Fe}$ followed by $\mathrm{Mn}, \mathrm{Ni}$ and $\mathrm{Cr}$. The presence of higher concentration of heavy metals in water may cause health hazards to the population of the area (Singh et al., 2009). The concentration of Fe in waters ranging from trace to $0.89 \mathrm{mg} \mathrm{L}^{-1}$ with an average value of $0.495 \mathrm{mg} \mathrm{L}^{-1}$ (Table 3). According to Ayers and Westcot (1985), the maximum recommended concentration of $\mathrm{Fe}$ in water used for irrigation is 5.0 $\mathrm{mg} \mathrm{L}^{-1}$ and according to DEP (2010), the maximum recommended concentration of $\mathrm{Fe}$ in surface water is $1.0 \mathrm{mg} \mathrm{L}^{-1}$. Considering these limits as standard, amount of Fe in all water samples of the study area were below the recommended limits, which indicates that all water samples were suitable for different uses.

The concentration of $\mathrm{Mn}$ in water samples collected from midstream of the river Karatoa varied from trace to $0.32 \mathrm{mg} \mathrm{L}^{-1}$ with a mean value of $0.10 \mathrm{mg} \mathrm{L}^{-1}$ (Table 3). According to Ayers and Westcot (1985), the maximum recommended limit of $\mathrm{Mn}$ in water used for irrigation is $0.20 \mathrm{mg} \mathrm{L}^{-1}$. Considering this limit as standard, amount of $\mathrm{Mn}$ in all water samples except one (Sample ID 19) of the study area were below the recommended value. According to surface water quality guideline, the maximum permissible limit of $\mathrm{Mn}$ is $0.1 \mathrm{mg} \mathrm{L}^{-1}$ (DEP, 2010). Considering this value, out of the 31 samples, 18 samples were within the permissible limit and the rest 13 samples exceeded the limit, which may problematic for different uses in respect of Mn concentration. The concentration of $\mathrm{Cr}$ in water samples varied from 0.002 to $0.009 \mathrm{mg} \mathrm{L}^{-1}$ with an average value of 0.005 $\mathrm{mg} \mathrm{L}^{-1}$. The concentration of $\mathrm{Ni}$ in water samples collected from the Karatoa river ranged from 0.001 to
$0.012 \mathrm{mg} \mathrm{L}^{-1}$ with a mean value of $0.005 \mathrm{mg} \mathrm{L}^{-1}$ (Table 3). According to USEPA (1999), the maximum recommended limit of $\mathrm{Cr}$ and $\mathrm{Ni}$ in water used for irrigation are 0.011 and $0.052 \mathrm{mg} \mathrm{L}^{-1}$, respectively. Considering these limits as standard, amount of $\mathrm{Cr}$ and $\mathrm{Ni}$ in all water samples of the study area were below the recommended value. Similarly, the water samples collected from midstream of the river Karatoa contained trace amount of $\mathrm{Cu}, \mathrm{Zn}$ and $\mathrm{Pb}$ (Table 3), which indicates that all of these water can safely be used for irrigation as well as other purposes in respect of these heavy metals.

\section{e) Suitability of water for irrigation usage}

The important characteristics or properties of water to be considered for irrigation use are electrical conductivity, salinity, percent sodium, sodium adsorption ratio, residual sodium carbonate and permeability index.

\section{(i) Sodium adsorption ratio (SAR)}

A high $\mathrm{Na}$ concentration changes soil properties and reduces soil permeability, which leads to development of an alkaline soil (Singh et al., 2010). The $\mathrm{Na}$ or alkali hazard is determined by the absolute and relative concentration of cations and is expressed in terms of the SAR, which is determined by the following formula:

$$
\begin{aligned}
\mathrm{SAR}= & \mathrm{Na}^{+} / \sqrt{\left(\mathrm{Ca}^{2+}+\mathrm{Mg}^{2+}\right) / 2} \\
& {\left[\text { all concentrations in meq } \mathrm{L}^{-1}\right] }
\end{aligned}
$$

The computed sodium adsorption ratio (SAR) of water samples ranged from 0.60 to 1.00 with a mean value of 0.75 (Table 4). Among the 31 samples, 22 samples were found below the average value and the rest 9 samples had more than the average value. Considering SAR value, Todd (1980) categorized irrigation waters into 4 groups, and considering this classification, all water samples were graded as excellent category for irrigation purpose. The present investigation revealed that a good proportion of $\mathrm{Ca}$ and $\mathrm{Mg}$ existed in all waters. These were suitable for good structure and tilth condition of soil and also the improvement of soil permeability. The irrigation water with SAR less than 10 might not be harmful for agricultural crops (Todd, 1980). The plot of data on the US salinity diagram, in which the EC is taken as salinity hazard and SAR as alkalinity hazard, shows that water samples fall in the categories of C2S1 and $\mathrm{C} 3 \mathrm{~S} 1$ indicating medium to high salinity and low alkali water (Fig. 2). High salinity water cannot be used on soils with restricted drainage and it requires special management for salinity control (such as good drainage, high leaching and organic matter addition) and plants with good salt tolerance should be selected for such area. Low sodium water (S1) can be used for irrigation on almost all soils with little danger of the development of harmful levels of exchangeable sodium. 
Table 2. pH, EC, TDS, DO and major anionic constituents of water collected from midstream of Karatoa river in Bangladesh

\begin{tabular}{|c|c|c|c|c|c|c|c|c|c|c|}
\hline $\begin{array}{c}\text { Sample } \\
\text { ID }\end{array}$ & pH & $\begin{array}{c}\mathrm{EC} \\
\mu \mathrm{S} \mathrm{\textrm {cm } ^ { - 1 }}\end{array}$ & $\begin{array}{c}\text { DO } \\
\text { mg L }^{-1}\end{array}$ & $\begin{array}{c}\text { TDS } \\
\text { mg L }^{-1}\end{array}$ & $\begin{array}{c}\text { Cl } \\
\text { me } L^{-1}\end{array}$ & $\begin{array}{c}\mathrm{CO}_{3}{ }^{2-} \\
\mathrm{me} \mathrm{L}^{-1}\end{array}$ & $\begin{array}{l}\mathrm{HCO}_{3}^{-} \\
\mathrm{me} \mathrm{L}^{-1}\end{array}$ & $\begin{array}{c}\mathrm{BO}_{3}{ }^{3-} \\
\mu \mathrm{g} \mathrm{mL}^{-1}\end{array}$ & $\begin{array}{c}\mathrm{PO}_{4}{ }^{3-} \\
\mu \mathrm{g} \mathrm{mL}{ }^{-1}\end{array}$ & $\begin{array}{c}\mathrm{SO}_{4}{ }^{2-} \\
\mu \mathrm{g} \mathrm{mL}{ }^{-1}\end{array}$ \\
\hline 1 & 7.22 & 450 & 0.40 & 293 & 3.17 & Trace & 4.00 & 0.61 & 2.02 & 8.83 \\
\hline 2 & 7.30 & 736 & 0.40 & 291 & 2.96 & Trace & 2.00 & 0.66 & 1.88 & 7.92 \\
\hline 3 & 7.15 & 706 & 0.50 & 286 & 3.03 & Trace & 2.20 & 0.55 & 2.13 & 8.92 \\
\hline 4 & 7.32 & 728 & 0.50 & 309 & 3.03 & Trace & 2.40 & 0.58 & 1.64 & 6.25 \\
\hline 5 & 7.01 & 736 & 0.30 & 306 & 2.96 & Trace & 2.40 & 0.52 & 2.12 & 5.92 \\
\hline 6 & 7.10 & 724 & 0.50 & 303 & 2.96 & Trace & 2.80 & 0.55 & 1.72 & 5.83 \\
\hline 7 & 7.22 & 748 & 0.40 & 308 & 3.03 & Trace & 2.00 & 0.58 & 1.36 & 6.08 \\
\hline 8 & 7.36 & 765 & 0.40 & 328 & 3.10 & Trace & 2.20 & 0.52 & 1.41 & 5.83 \\
\hline 9 & 7.36 & 800 & 0.40 & 330 & 3.24 & Trace & 2.20 & 0.63 & 1.16 & 7.25 \\
\hline 10 & 7.27 & 740 & 0.40 & 301 & 3.10 & Trace & 2.20 & 0.41 & 1.34 & 5.50 \\
\hline 11 & 7.35 & 706 & 0.40 & 282 & 2.96 & Trace & 2.60 & 0.55 & 1.31 & 5.58 \\
\hline 12 & 7.29 & 564 & 0.40 & 247 & 2.96 & Trace & 2.00 & 0.63 & 1.33 & 6.33 \\
\hline 13 & 7.32 & 730 & 0.50 & 298 & 3.03 & Trace & 2.40 & 0.52 & 1.31 & 6.33 \\
\hline 14 & 7.32 & 719 & 0.40 & 291 & 2.96 & Trace & 2.60 & 0.47 & 1.99 & 7.17 \\
\hline 15 & 7.25 & 732 & 0.50 & 312 & 2.89 & Trace & 3.00 & 0.61 & 1.84 & 6.75 \\
\hline 16 & 7.70 & 1224 & 0.40 & 562 & 5.36 & Trace & 2.60 & 0.69 & 1.36 & 25.92 \\
\hline 17 & 7.14 & 736 & 0.50 & 312 & 3.03 & Trace & 2.60 & 0.77 & 1.47 & 5.92 \\
\hline 18 & 7.29 & 737 & 0.40 & 308 & 2.96 & Trace & 2.20 & 0.79 & 2.16 & 5.42 \\
\hline 19 & 7.23 & 1653 & 0.40 & 789 & 5.36 & Trace & 8.00 & 1.35 & 1.95 & 23.33 \\
\hline 20 & 7.19 & 743 & 0.40 & 306 & 2.96 & Trace & 2.40 & 0.91 & 2.56 & 4.75 \\
\hline 21 & 7.24 & 678 & 0.40 & 276 & 2.75 & Trace & 2.00 & 0.55 & 1.60 & 4.25 \\
\hline 22 & 7.34 & 679 & 0.40 & 270 & 2.89 & Trace & 2.00 & 0.47 & 1.23 & 3.58 \\
\hline 23 & 7.28 & 674 & 0.40 & 256 & 2.75 & Trace & 2.00 & 0.30 & 1.33 & 3.08 \\
\hline 24 & 7.01 & 688 & 0.40 & 272 & 2.82 & Trace & 2.40 & 0.58 & 1.13 & 4.08 \\
\hline 25 & 7.30 & 678 & 0.40 & 279 & 2.75 & Trace & 2.00 & 0.61 & 1.21 & 5.50 \\
\hline 26 & 7.38 & 660 & 0.40 & 277 & 2.61 & Trace & 2.00 & 0.44 & 1.18 & 4.92 \\
\hline 27 & 7.51 & 656 & 0.40 & 269 & 2.61 & Trace & 2.20 & 0.49 & 1.28 & 5.25 \\
\hline 28 & 6.98 & 705 & 0.40 & 288 & 2.89 & Trace & 2.20 & 0.52 & 1.34 & 3.92 \\
\hline 29 & 7.18 & 780 & 0.50 & 326 & 2.68 & Trace & 2.80 & 0.36 & 1.46 & 6.33 \\
\hline 30 & 7.34 & 672 & 0.40 & 283 & 2.75 & Trace & 2.00 & 0.47 & 1.49 & 6.67 \\
\hline 31 & 7.62 & 1131 & 0.40 & 513 & 4.23 & Trace & 4.00 & 0.47 & 1.60 & 17.00 \\
\hline Max. & 7.70 & 1653 & 0.50 & 789 & 5.36 & Trace & 8.00 & 1.35 & 2.56 & 25.92 \\
\hline Min. & 6.98 & 450 & 0.30 & 247 & 2.61 & Trace & 2.00 & 0.30 & 1.13 & 3.08 \\
\hline Mean & 7.28 & 763.81 & 0.42 & 324.87 & 3.12 & - & 2.59 & 0.59 & 1.58 & 7.43 \\
\hline SD & 0.16 & 213.33 & 0.05 & 107.55 & 0.66 & - & 1.12 & 0.19 & 0.37 & 5.19 \\
\hline
\end{tabular}


Table 3. Heavy metals and major cationic concentrations $\left(\mu \mathrm{g} \mathrm{mL} \mathrm{m}^{-1}\right)$ of water collected from midstream of Karatoa river in Bangladesh

\begin{tabular}{|c|c|c|c|c|c|c|c|c|c|c|c|}
\hline $\begin{array}{c}\text { Sample } \\
\text { ID }\end{array}$ & $\mathrm{Ca}$ & Mg & $\mathbf{N a}$ & $\mathbf{K}$ & $\mathrm{Fe}$ & Mn & $\mathrm{Cu}$ & $\mathbf{Z n}$ & $\mathbf{P b}$ & $\mathrm{Cr}$ & $\mathbf{N i}$ \\
\hline 1 & 41.68 & 17.49 & 16.08 & 15.85 & 0.51 & 0.18 & Trace & Trace & Trace & 0.005 & 0.004 \\
\hline 2 & 40.08 & 18.47 & 15.28 & 16.25 & 0.52 & 0.19 & Trace & Trace & Trace & 0.006 & 0.008 \\
\hline 3 & 41.08 & 15.56 & 14.48 & 15.44 & 0.51 & 0.18 & Trace & Trace & Trace & 0.007 & 0.009 \\
\hline 4 & 44.89 & 16.53 & 14.88 & 16.25 & 0.39 & 0.15 & Trace & Trace & Trace & 0.004 & 0.004 \\
\hline 5 & 46.49 & 15.56 & 15.28 & 16.25 & 0.25 & 0.11 & Trace & Trace & Trace & 0.004 & 0.007 \\
\hline 6 & 48.09 & 03.89 & 12.48 & 14.23 & 0.51 & 0.07 & Trace & Trace & Trace & 0.002 & 0.003 \\
\hline 7 & 40.08 & 16.53 & 15.28 & 15.44 & Trace & Trace & Trace & Trace & Trace & 0.003 & 0.004 \\
\hline 8 & 40.08 & 18.47 & 17.28 & 15.85 & Trace & 0.06 & Trace & Trace & Trace & 0.008 & 0.011 \\
\hline 9 & 40.08 & 14.58 & 17.68 & 16.66 & 0.13 & 0.07 & Trace & Trace & Trace & 0.004 & 0.002 \\
\hline 10 & 51.30 & 12.63 & 16.08 & 15.44 & 0.25 & Trace & Trace & Trace & Trace & 0.002 & 0.002 \\
\hline 11 & 54.51 & 12.63 & 15.28 & 16.25 & Trace & 0.04 & Trace & Trace & Trace & 0.003 & 0.004 \\
\hline 12 & 48.09 & 13.61 & 15.28 & 15.04 & 0.63 & Trace & Trace & Trace & Trace & 0.003 & 0.007 \\
\hline 13 & 42.29 & 12.64 & 16.48 & 14.63 & 0.57 & 0.11 & Trace & Trace & Trace & 0.005 & 0.009 \\
\hline 14 & 51.30 & 11.67 & 15.68 & 15.85 & 0.51 & 0.07 & Trace & Trace & Trace & 0.006 & 0.007 \\
\hline 15 & 48.09 & 13.61 & 14.88 & 16.25 & 0.13 & 0.14 & Trace & Trace & Trace & 0.005 & 0.005 \\
\hline 16 & 70.54 & 30.13 & 24.48 & 8.95 & Trace & 0.07 & Trace & Trace & Trace & 0.004 & 0.007 \\
\hline 17 & 43.28 & 16.53 & 16.08 & 16.25 & Trace & 0.06 & Trace & Trace & Trace & 0.008 & 0.012 \\
\hline 18 & 48.09 & 13.61 & 14.48 & 17.07 & 0.13 & 0.04 & Trace & Trace & Trace & 0.009 & 0.010 \\
\hline 19 & 70.54 & 27.22 & 24.88 & 12.60 & 0.38 & 0.32 & Trace & Trace & Trace & 0.005 & 0.004 \\
\hline 20 & 40.08 & 19.44 & 15.68 & 17.47 & 0.29 & 0.18 & Trace & Trace & Trace & 0.003 & 0.002 \\
\hline 21 & 35.27 & 09.72 & 14.88 & 15.04 & 0.25 & 0.04 & Trace & Trace & Trace & 0.004 & 0.005 \\
\hline 22 & 24.05 & 06.81 & 15.28 & 13.41 & 0.24 & 0.05 & Trace & Trace & Trace & 0.002 & 0.001 \\
\hline 23 & 38.47 & 12.64 & 14.48 & 14.23 & 0.25 & 0.04 & Trace & Trace & Trace & 0.004 & 0.003 \\
\hline 24 & 40.08 & 18.47 & 14.88 & 14.63 & 0.43 & 0.06 & Trace & Trace & Trace & 0.004 & 0.003 \\
\hline 25 & 43.28 & 22.36 & 15.68 & 13.82 & 0.63 & 0.07 & Trace & Trace & Trace & 0.002 & 0.001 \\
\hline 26 & 43.28 & 24.31 & 14.08 & 13.41 & 0.89 & 0.11 & Trace & Trace & Trace & 0.007 & 0.009 \\
\hline 27 & 38.47 & 10.69 & 13.28 & 13.41 & 0.78 & 0.09 & Trace & Trace & Trace & 0.005 & 0.006 \\
\hline 28 & 35.27 & 12.63 & 15.28 & 15.89 & 0.76 & 0.07 & Trace & Trace & Trace & 0.006 & 0.004 \\
\hline 29 & 40.08 & 14.58 & 13.28 & 13.82 & 0.63 & 0.11 & Trace & Trace & Trace & 0.002 & 0.002 \\
\hline 30 & 40.08 & 14.58 & 12.88 & 21.53 & 0.51 & 0.14 & Trace & Trace & Trace & 0.003 & 0.005 \\
\hline 31 & 44.89 & 23.33 & 22.08 & 8.55 & 0.76 & 0.14 & Trace & Trace & Trace & 0.003 & 0.005 \\
\hline Max. & 70.54 & 30.13 & 24.88 & 21.53 & 0.89 & 0.32 & Trace & Trace & Trace & 0.009 & 0.012 \\
\hline Min. & 24.05 & 3.89 & 12.48 & 8.55 & Trace & Trace & Trace & Trace & Trace & 0.002 & 0.001 \\
\hline Mean & 44.32 & 15.84 & 15.94 & 15.03 & 0.495 & 0.101 & - & - & - & 0.005 & 0.005 \\
\hline SD & 9.04 & 5.53 & 2.88 & 2.34 & 0.247 & 0.067 & - & - & - & 0.002 & 0.003 \\
\hline
\end{tabular}


Table 4. Quality rating and suitability of water for irrigation collected from the midstream of Karatoa river in Bangladesh

\begin{tabular}{|c|c|c|c|c|c|c|c|c|}
\hline \multirow{2}{*}{$\begin{array}{c}\text { Sample } \\
\text { ID }\end{array}$} & \multirow{2}{*}{ SAR } & \multirow{2}{*}{$\begin{array}{c}\text { SSP } \\
\%\end{array}$} & \multirow{2}{*}{$\begin{array}{c}\text { RSC }^{-1} \\
\text { meL }^{-1}\end{array}$} & \multirow{2}{*}{$\begin{array}{l}\text { Hardness } \\
\mathrm{mg} \mathrm{L}^{-1}\end{array}$} & \multicolumn{4}{|c|}{ Water class based on } \\
\hline & & & & & $\mathbf{S A R}^{1}$ & $\mathbf{S S P}^{2}$ & $\mathbf{R S C}^{3}$ & Hardness $^{4}$ \\
\hline 1 & 0.74 & 38.35 & 2.24 & 175.91 & Ex. & Good & Mar. & Hard \\
\hline 2 & 0.71 & 37.82 & 0.24 & 175.93 & Ex. & Good & Suit. & Hard \\
\hline 3 & 0.69 & 37.87 & 0.54 & 166.49 & Ex. & Good & Suit. & Hard \\
\hline 4 & 0.66 & 36.91 & 0.60 & 179.99 & Ex. & Good & Suit. & Hard \\
\hline 5 & 0.70 & 37.28 & 0.60 & 180.02 & Ex. & Good & Suit. & Hard \\
\hline 6 & 0.66 & 39.79 & 1.44 & 136.17 & Ex. & Good & Mar. & $\mathrm{MH}$ \\
\hline 7 & 0.72 & 38.46 & 0.32 & 167.97 & Ex. & Good & Suit. & Hard \\
\hline 8 & 0.85 & 39.47 & 0.44 & 175.93 & Ex. & Good & Suit. & Hard \\
\hline 9 & 0.86 & 42.55 & 0.60 & 159.98 & Ex. & Perm. & Suit. & Hard \\
\hline 10 & 0.74 & 37.62 & 0.40 & 180.03 & Ex. & Good & Suit. & Hard \\
\hline 11 & 0.69 & 36.28 & 0.72 & 188.06 & Ex. & Good & Suit. & Hard \\
\hline 12 & 0.71 & 37.16 & 0.24 & 176.03 & Ex. & Good & Suit. & Hard \\
\hline 13 & 0.81 & 40.72 & 0.83 & 157.55 & Ex. & Perm. & Suit. & Hard \\
\hline 14 & 0.73 & 37.96 & 0.84 & 176.09 & Ex. & Good & Suit. & Hard \\
\hline 15 & 0.69 & 37.45 & 1.24 & 176.03 & Ex. & Good & Suit. & Hard \\
\hline 16 & 0.87 & 30.04 & 0.40 & 299.88 & Ex. & Good & Suit. & Hard \\
\hline 17 & 0.74 & 38.55 & 0.84 & 175.97 & Ex. & Good & Suit. & Hard \\
\hline 18 & 0.67 & 37.51 & 0.44 & 176.03 & Ex. & Good & Suit. & Hard \\
\hline 19 & 0.90 & 32.65 & 5.12 & 287.95 & Ex. & Good & Unsuit. & Hard \\
\hline 20 & 0.72 & 38.33 & 0.60 & 179.90 & Ex. & Good & Suit. & Hard \\
\hline 21 & 0.81 & 44.44 & 0.72 & 128.03 & Ex. & Perm. & Suit. & $\mathrm{MH}$ \\
\hline 22 & 1.00 & 53.17 & 1.12 & 88.05 & Ex. & Perm. & Suit. & $\mathrm{MH}$ \\
\hline 23 & 0.73 & 39.96 & 0.52 & 147.99 & Ex. & Good & Suit. & $\mathrm{MH}$ \\
\hline 24 & 0.69 & 36.54 & 0.64 & 175.93 & Ex. & Good & Suit. & Hard \\
\hline 25 & 0.68 & 33.94 & 0.01 & 199.88 & Ex. & Good & Suit. & Hard \\
\hline 26 & 0.60 & 31.29 & -0.08 & 207.87 & Ex. & Good & Suit. & Hard \\
\hline 27 & 0.69 & 39.47 & 0.79 & 140.00 & Ex. & Good & Suit. & MH \\
\hline 28 & 0.79 & 43.13 & 0.80 & 139.96 & Ex. & Perm. & Suit. & $\mathrm{MH}$ \\
\hline 29 & 0.72 & 36.62 & 1.20 & 159.98 & Ex. & Good & Suit. & Hard \\
\hline 30 & 0.63 & 43.12 & 0.39 & 159.98 & Ex. & Perm. & Suit. & Hard \\
\hline 31 & 0.94 & 36.09 & 1.92 & 207.88 & Ex. & Good & Mar. & Hard \\
\hline Max. & 1.00 & 53.17 & 5.12 & 299.88 & - & - & - & - \\
\hline Min. & 0.60 & 30.04 & -0.08 & 88.05 & - & - & - & - \\
\hline Mean & 0.75 & 38.40 & 0.86 & 174.25 & & & & \\
\hline SD & 0.09 & 4.19 & 0.93 & 41.09 & & & & \\
\hline
\end{tabular}

Legend: Ex. = Excellent, Perm. $=$ Permissible, $\mathrm{MH}=$ Moderately hard, Suit. $=$ Suitable, Unsuit.= Unsuitable, Mar. = Marginal, ${ }^{1,2,3 \& 4}=$ Todd (1980), Wilcox (1955), Ghosh et al. (1983) and Sawyer and McCarty (1967) 


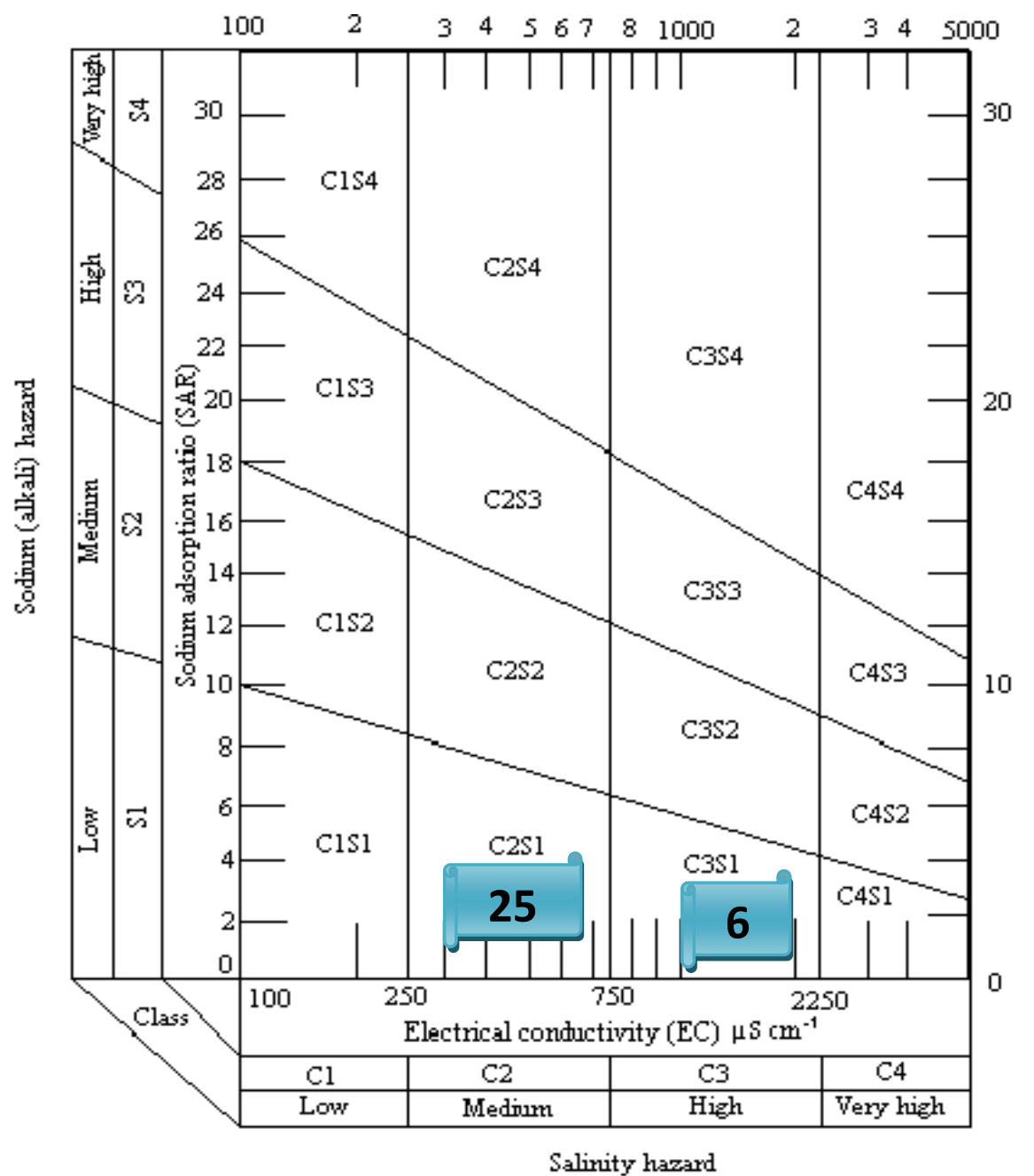

Fig. 2. Diagram for classifying irrigation water on the basis of SAR and EC as described by Richards (1968)

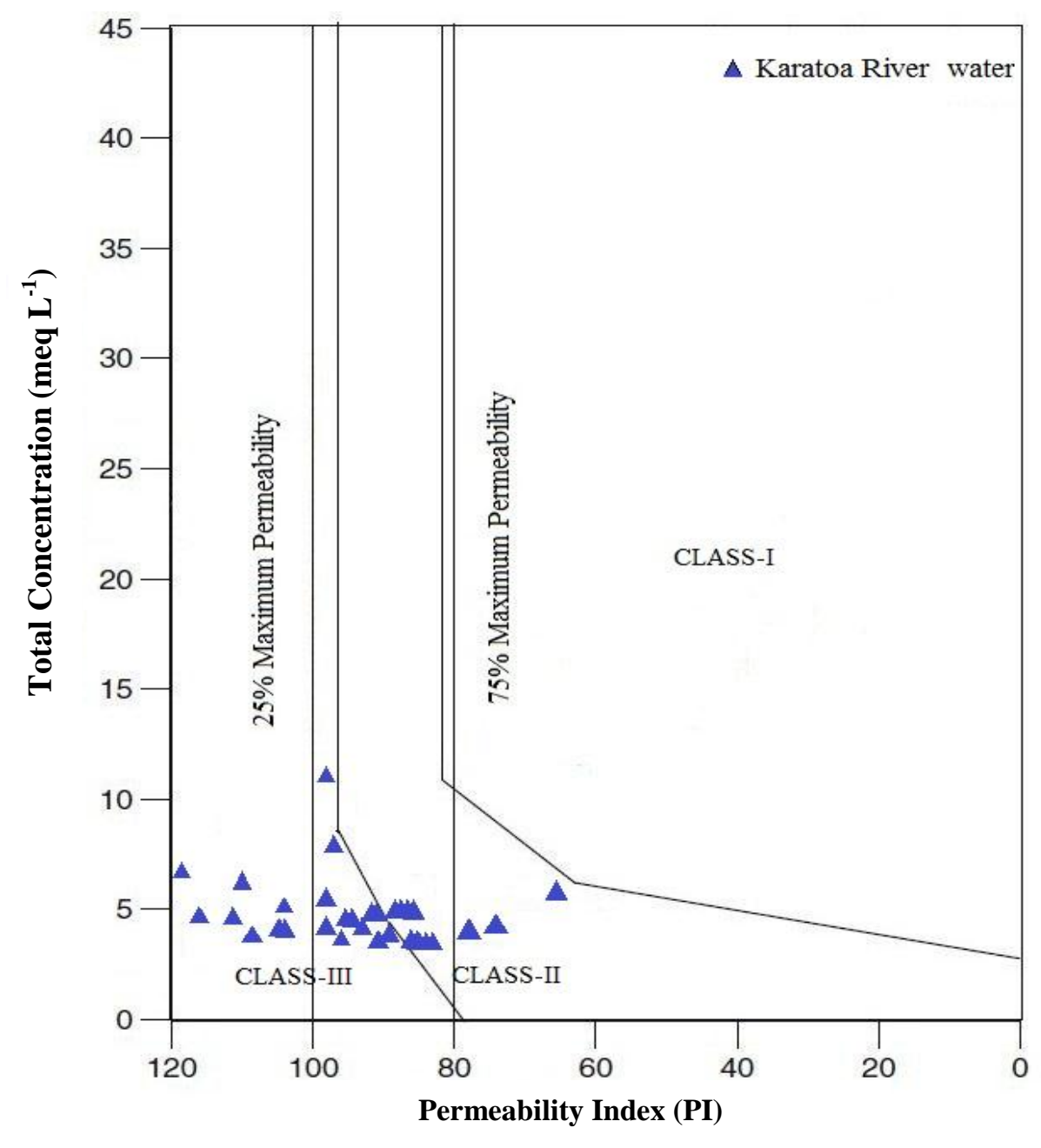

Fig. 3. Diagram for classifying irrigation waters on the basis of permeability index as described by Doneen (1964) 


\section{(ii) Soluble sodium percentage (SSP)}

Percent $\mathrm{Na}$ is widely used for evaluating the suitability of water for irrigation (Wilcox, 1955). High $\mathrm{Na}$ irrigation water causes exchange of $\mathrm{Na}$ in water for $\mathrm{Ca}$ and $\mathrm{Mg}$ in soil, reduces permeability, and eventually results in soil with poor internal drainage. Hence, air and water circulation is restricted during wet conditions and such soils are usually hard when dry (Collins and Jenkins, 1996; Saleh et al., 1999). The Indian Standard (BIS, 1991) recommends a maximum SSP of $60 \%$ for irrigation water, where SSP is calculated by:

$$
\mathrm{SSP}=\left[\left(\mathrm{Na}^{+}+\mathrm{K}^{+}\right) \times 100\right] /\left(\mathrm{Ca}^{2+}+\mathrm{Mg}^{2+}+\mathrm{Na}^{+}+\mathrm{K}^{+}\right)
$$$$
\text { [all concentrations in meq } \mathrm{L}^{-1} \text { ] }
$$

The calculated SSP value of all collected water samples varied from 30.04 to $53.17 \%$ with the mean value of $38.40 \%$ (Table 4). According to water classification proposed by Wilcox (1955), out of 31 water samples, 25 samples were classified as good (SSP $=0-40 \%)$ and the rest 6 samples were classified as permissible (SSP $=40-60 \%$ ). In the study area, the water having good to permissible classes might safely be applied for irrigating agricultural crops.

\section{(iii) Residual sodium carbonate (RSC)}

The quantity of bicarbonate and carbonate in excess of alkaline earths $\left(\mathrm{Ca}^{2+}+\mathrm{Mg}^{2+}\right)$ also influence the suitability of water for irrigation purposes. When the sum of carbonates and bicarbonates is in excess of calcium and magnesium, precipitation $\mathrm{Ca}$ and $\mathrm{Mg}$ may occur (Raghunath, 1987). The effects of carbonate and bicarbonate, and suitability of water for irrigation can be assessed by computing residual sodium carbonate (RSC) values as follows:

$$
\begin{aligned}
\mathrm{RSC}= & \left(\mathrm{CO}_{3}{ }^{2-}+\mathrm{HCO}_{3}{ }^{-}\right)-\left(\mathrm{Ca}^{2+}+\mathrm{Mg}^{2+}\right) \\
& {\left[\text { all concentrations in meq } \mathrm{L}^{-1}\right] }
\end{aligned}
$$

A high RSC value in water leads to an increase in the adsorption of $\mathrm{Na}$ on soil. Irrigation waters having RSC values greater than $5 \mathrm{meq} \mathrm{L}^{-1}$ are considered harmful to the growth of plants, while waters with RSC value above $2.5 \mathrm{meq} \mathrm{L}^{-1}$ are not considered suitable for irrigation. Hence, continued usage of high RSC waters will affect the yields of crop. The computed RSC varied from -0.08 to 5.12 meq $\mathrm{L}^{-1}$ with mean value of 0.86 meq $\mathrm{L}^{-1}$ (Table 4). Among the water samples under test, 1 sample exhibited negative value. According to Ghosh et al. (1983), out of 31 water samples, 27 samples were found in suitable class ( $\mathrm{RSC}<1.25 \mathrm{meq} \mathrm{L}^{-1}$ ), 3 samples were in marginal class $(\mathrm{RSC}=1.25-2.50$ meq $\left.\mathrm{L}^{-1}\right)$, and the rest 1 sample was in unsuitable class $\left(\mathrm{RSC}>2.50 \mathrm{meq} \mathrm{L}^{-1}\right)$.

\section{(iv) Hardness $\left(\mathrm{H}_{T}\right)$}

Water hardness has no known adverse effects on human; however, some evidence indicates its role in heart disease (WHO, 2008). Hardness of water resulted due to the abundant presence of divalent cations like $\mathrm{Ca}^{2+}$ and $\mathrm{Mg}^{2+}$ (Todd, 1980). Hard water is unsuitable for domestic usage, as well as hardness of water limits its use for industrial purposes; causing scaling of pots, boilers and irrigation pipes may cause health problems to humans, such as kidney failure (WHO, 2008). Hardness of water was computed by the following formula:

$$
\mathrm{H}_{\mathrm{T}}=2.5 \times \mathrm{Ca}^{2+}+4.1 \times \mathrm{Mg}^{2+}
$$

The calculated hardness of all water samples varied from 88.05 to $299.88 \mathrm{mg} \mathrm{L}^{-1}$ with the mean value of $174.25 \mathrm{mg} \mathrm{L}^{-1}$ (Table 4). On the basis of total hardness, water can be classified as soft $\left(<75 \mathrm{mg} \mathrm{L}^{-}\right.$ $\left.{ }^{1}\right)$, moderately hard (75-150 mg L $\left.{ }^{-1}\right)$, hard (150-300 $\mathrm{mg} \mathrm{L}^{-1}$ ) and very hard (> $300 \mathrm{mg} \mathrm{L}^{-1}$ ) (Sawyer and McCarty 1967). According to the criteria described above, out of 31 water samples, 6 samples were graded as moderately hard and the rest 25 samples were graded as hard.

\section{(v) Permeability index (PI)}

Soil permeability is affected by long term use of water rich in $\mathrm{Na}^{+}, \mathrm{Ca}^{2+}, \mathrm{Mg}^{2+}$, and $\mathrm{HCO}_{3}^{-}$. The PI is also used to assess suitability of water for irrigation and is defined as follows:

$$
\begin{gathered}
\mathrm{PI}=\left[\left(\mathrm{Na}^{+}+\sqrt{ } \mathrm{HCO}_{3}^{-}\right) \times 100\right] /\left(\mathrm{Ca}^{2+}+\mathrm{Mg}^{2+}+\mathrm{Na}^{+}\right) \\
{[\text {all concentrations in meq L }} \\
-1
\end{gathered}
$$

Doneen (1964) classified irrigation waters in three PI classes. Class-I and Class-II water types are suitable for irrigation with $75 \%$ or more of maximum permeability, while Class-III types of water, with $25 \%$ of maximum permeability, are unsuitable for irrigation. Plotting our data on Doneen's chart indicates that $35.5 \%$ of the water samples fall in Class-II, implying that the water is good for irrigation usage (Domenico and Schwartz 1990). However, $64.5 \%$ of the water samples collected from midstream of Karatoa river belongs to Class- III, the unsuitable category (Fig. 3).

\section{Conclusion}

The collected water samples of midstream of Karatoa river is neutral to slight alkaline. The EC of all collected water samples show medium to high salinity and DO indicating that the aquatic life in the study area is in under stress. On the basis of $\mathrm{K}^{+}$ content, all of the water samples exceeded the limit $\left(2.0 \mathrm{mg} \mathrm{L}^{-1}\right)$ for irrigation usage but in context of $\mathrm{Ca}^{2+}, \mathrm{Mg}^{2+}$ and $\mathrm{Na}^{+}$, all water samples under the 
study area could safely be applied for long-term irrigation without any harmful effect on both soils and crops. Similarly, in respect of $\mathrm{Cl}^{-}, \mathrm{BO}_{3}{ }^{3-}, \mathrm{PO}_{4}{ }^{3-}$ and $\mathrm{SO}_{4}^{2-}$ content, only $3,1,5$ and 2 water samples, respectively were problematic for irrigation purpose. Among the studied heavy metals $(\mathrm{Fe}, \mathrm{Zn}, \mathrm{Cu}, \mathrm{Pb}, \mathrm{Cr}$, $\mathrm{Ni}$ and $\mathrm{Mn}$ ), the most dominant metal was $\mathrm{Fe}$ and $\mathrm{Mn}$. In respect of Mn content, out of 31 samples, 1 and 13 water samples were exceeded the maximum permissible limit for irrigation and surface water quality guideline, respectively. High values of RSC, $\mathrm{H}_{\mathrm{T}}$ and PI at some sites in midstream of Karatoa river restrict their use for irrigation. However, suitable water treatment and a soil management plan are needed for their use for this purpose in such areas.

\section{References}

Agarwal, R. R.; Yadav, J. P. and Gupta, R. N. 1982. Saline and Alkali Soils of India. Indian Council of Agricultural Research, New Delhi, India. pp. 223-228.

Akbal F.; Gurel, L.; Bahadyr, T.; Guler, I. L.; Bakan, G. and Ngor, H. B. Y. K. 2011. Water and sediment quality assessment in the mid-Black Sea coast of Turkey using multivariate statistical techniques. Environmental Earth Science, 64:1387-1395.

APHA (American Public Health Association). 1995. Standard Methods for the Examination of Water and Waste Water. $19^{\text {th }}$ ed., Washington DC, 1019 pages.

Appelo, C. A. J. and Postma, D. 1993. Geochemistry, Groundwater and Pollution. $2^{\text {nd }}$ ed., A A Balkema Publisher, Rotterdam. 536 pages.

Ayers, R. S. and Westcot, D. W. 1985. Water Quality for Agriculture. FAO Irrigation and Drainage Paper. 29 (Rev. 1): 4096.

Berner, E. K. and Berner, R. A. 1987. The Global Water Cycle: Geochemistry and Environment. Prentice-Hall, Englewood Cliffs, 387 pages.

BIS (1991) Indian Standards Institution-Indian standard specification for drinking water. IS: 10500 .

Collins, R. and Jenkins, A. 1996. The impact of agricultural land use on stream chemistry in the middle hills of the Himalayas, Nepal. Journal of Hydrology, 185:71-86.

Das, G. S.; Tiwari, B. K. and Tripathi, R. S. 2002. Coal mining in Jaintia hills, Meghalaya: An ecological perspective. In: Jaintia Hills, A Meghalaya Tribe: Its Environment, Land and People. (Passah, P.M. and Sarma, A.S. Eds.). Reliance Publishing House, New Delhi. pp. 121-128.
DEP (Department of Environmental Protection). 2010. Surface Water Quality Standards. Chapter 62302, Tallahassee, FL-32399, USA.

Domenico, P. A. and Schwartz, F. W. 1990. Physical and Chemical Hydrologeology. $2^{\text {nd }}$ ed., Wiley, New York, 528 pages.

Doneen, L. D. 1964. Notes on Water Quality in Agriculture. Water science and engineering paper 4001, Department of Water Sciences and Engineering, University of California, Davis.

Freeze, A. R. and Cherry, J. A. 1979. Groundwater. Prentice Hall Inc., Englewood Cliffs, New Jersey, USA. 84 pages.

Ghosh, A. B.; Bajaj, J. C.; Hasan, R. and Singh, D. 1983. Soil and Water Testing Methods. A Laboratory Manual, Division of Soil Science and Agricultural Chemistry, IARI, New Delhi, India. pp. 1-48.

Gibeault, V. A. and Cockerham, S. T. 1985. Turfgrass, Water Conservation. ANR Publications, University of California, USA. 155 pages.

Ittefaq (The Daily Newspaper). 2010. Karatoa Jeno Mora Khal (in Bengali), 10 December, 2010, p. 20.

Karanth, K. R. 1994. Ground Water Assessment Development and Management. Tata McGrawHill Publishing Company Ltd, New Delhi, India. pp. 248- 250.

Mohiuddin, K. M.; Zakir, H. M.; Otomo, K.; Sharmin, S. and Shikazono, N. 2010. Geochemical distribution of trace metal pollutants in water and sediments of downstream of an urban river. International Journal of Environmental Science and Technology, 7:17-28.

Raghunath, H. M. 1987. Ground Water. Wiley Eastern Ltd. Delhi, India.

Rao, B. K.; Panchaksharjah, S.; Patil, B. N.; Narayana, A. and Kaiker, D. L. S. 1982. Chemical composition of irrigation waters from selected parts of Bijpur district, Karnataka. Mysore Journal of Agricultural Science, 16(4):426-432.

Richards, L. A. 1968. Diagnosis and Improvement of Saline and Alkali Soils. Agricultural Handbook \# 60 (ed.), USDA and IBH Publishing Co. Ltd., New Delhi, India. pp. 98-99.

Saleh, A.; Al-Ruwaih, F. and Shehata, M. 1999. Hydrogeochemical processes operating within the main aquifers of Kuwait. Journal of Arid Environment, 42:195-209.

Sawyer, C. N. and McCarty, P. L. 1967. Chemistry of Sanitary Engineers. $2^{\text {nd }}$ edn., McGraw Hill, NewYork, 518 pages.

Shikazono, N.; Tatewaki, K.; Mohiuddin, K. M.; Nakano, T. and Zakir, H. M. 2012. Sources, spatial variation and speciation of heavy metals 
in sediments of the Tamagawa river in Central Japan. Environmental Geochemistry and Health, 34:13-26.

Sincero, Sr. A. P. and Sincero, G. A. 2004. Environmental Engineering: A Design Approach. Prentice-Hall of India Private Ltd, New Delhi, India, pp 120-122.

Singh, A. K.; Mahato, M. K.; Neogi, B. and Singh, K. K. 2010. Quality assessment of mine water in the Raniganj coalfield area, India. Mine Water and the Environment, 29:248-262.

Singh, A. K.; Mondal, G. C.; Kumar, S.; Singh, T. B.; Tewary, B. K. and Sinha, A. 2009. Major ion chemistry, weathering processes and water quality assessment in upper catchment of Damodar River basin, India. Environmental Geology, 54:745-758.

Srinivasamoorthy, K.; Vijayaraghavan, K.; Vasanthavigar, M.; Sarma, V. S.; Rajivgandhi, R.; Chidambaram, S.; Anandhan, P. and Manivannan, R. 2011. Assessment of groundwater vulnerability in Mettur region, Tamilnadu, India using drastic and GIS techniques. Arabian Journal of Geoscience, 4:1215-1228.
Todd, D. K. 1980. Groundwater Hydrology. $2^{\text {nd }}$ edn., John Wiley and Sons Inc., New York, USA. 304 pages.

USEPA (U.S. Environmental Protection Agency). 1999. Screening Level Ecological Risk Assessment Protocol. Appendix E: Toxicity Reference values U.S. EPA Region 6. Office of Solid waste.

WHO (World Health Organization). 2008. Guidelines for Drinking Water Quality. Incorporating $1^{\text {st }}$ and $2^{\text {nd }}$ agenda, vol. 1 . Recommendations, $3^{\text {rd }}$ edn., WHO, Geneva, 515 pages.

Wilcox, L. V. 1955. Classification and Use of Irrigation Water. Cir. no. 969. Washington, USA. p.19.

Zakir, H. M.; Kohinoor Begum; Mohiuddin, K. M. and Arafat, M. Y. 2011. Quality assessment of waters of Bogra city area, Bangladesh. Journal of Agroforesty and Environment, 5:21-25

Zakir, H. M.; Sharmin, S. and Shikazono, N. 2006. Heavy metal pollution assessment in water and sediments of Turag River at Tongi area in Bangladesh. International Journal of Lakes and Rivers, 1(1):85-96. 